\title{
Neuroeducative Orientations to Provide a Better Development of the Superior Mental Functions in Children
}

\author{
Carla Anauate ${ }^{*}$ \\ Universidade Nove de Julho, Centro Integrado de Neuropsicologia e Psicologia, Brazil
}

\begin{abstract}
Considering that relations promote development of superior mental functions we believe that parents and teachers, should be present and paying attention to their children providing opportunity for an ideal neurodevelopment. It is important to orientate parents and teachers so they can provide conditions, with knowledge and conscience, for this development to occur. Neuroeducation emphasizes the need to stimulate the brain through effective and important relations. This work uses the Social Historical theory and Vygotsky's and Luria's postulates. We believe that the individual constitutes himself by means of social contact. This work has the goal to approach the theory which emphasizes this contact and orientate, with specific guidelines and practical work, parents and teachers aiming for a better child neurodevelopment. Bonds are necessary for a better and trustful relation. When you are in a significant relation nervous connections are stimulated and these lead to a more effective motor, cognitive and affective development.
\end{abstract}

Keywords: Children, development, relation, orientation.

\section{INTRODUCTION}

The neuropsychomotor development begins very early, even before the baby is born. Parents, when pregnant, start to build a significant bond with their baby. This bond, this relation is the key to a better and more complete possibility of child development. Bock [1] and Vygotsky [2] point out that a man is brought up only by means of social relations. Amiralian [3] aludes that, for Winnicott, a human being constitutes himself through the interactions of the environment with his personal experiences. Therefore establishing significant relations provides more means for a better appropriation of the experiences and of the world around.

This contact and exchange develops a human being. A child will be brought up through the relation that he will have with other people and be a result of this interaction they experienced. In this matter a child will internalize the world and form his subjectivity by means of the relations and the life he will live because subjectivity is socially constituted. González Rey [4] considers that the constitution of the individual subjectivity is a singular process that emerges from the person in contact with the actual environment. The social world becomes subjective when it is converted into something relevant for the development of the human being.

Aguiar [5] points out that man is in constant relation with the world interfering in it and at the same time being affected by it internalizing and registering it. Therefore the psychological world is constituted from the relations of man with the objective, social and cultural world. Man constitutes

*Address correspondence to this author at the Universidade Nove de Julho, Centro Integrado de Neuropsicologia e Psicologia;

E-mail: carla@ ramark.com.br his psychological world within the relation he has with the world, objectivating subjectivity and subjectivating objectivity.

The initial relation of men with the external environment are mediated: the child needs to manipulate the objects, live the situations and establish relations with other persons of the social environment to be able to appropriate, internalize, represent mentally the objects, events and relations. Vygotsky [6] states that this process of relational experience of the child is the propulsion for the development of the superior psychological functions.

Considering that parents and teachers are the mediators among the child and the world they will provide interaction which will permit the child to develop himself as a human being belonging to the universe. Vygotsky [6] refers that through the contact with a world of relations the child will internalize the instruments, the actions and the relations that are presented to him by the others allowing the development of the superior psychological functions. In this way the child will grow as a social and active human being.

\section{ORIENTATIONS TO PARENTS}

This paper has the intention to provide orientations to parents and teachers of how to promote a better neuropsychomotor development to children. This is a very important thematic in terms of successful learning of school abilities. We notice that this issue is in vogue among educators, psychologists and other professionals related to this area. So this article aims on elucidating this matter concerning that orientation provides means for a better and substantial development of the superior mental functions: attention, memory, psychomotricity, language, executive functions, thought, perception, etc. 
We consider orientation as something more important than prevention. It is an act of love, unconditional love. We never know who will be this child in the future, but mean while he needs love and care. Love does not choose specific characteristics, it is spontaneous, it does not elect color, sex, race or deficiency. Love is a natural feeling that is born and exists inside your heart. We intend through these ideas to emphasize that the relation of mother and child or teacher and student grows when love exists. Love is directly related to a good relation and attachment which is the first substantial step to intelligence. So it is essential to develop a good and important relation, to look and care, is fundamental for the acquisition of the ability of learning. Intelligence is built up within a good relation opening important paths for the development of the superior mental functions. We can say that one leads to the other: a good attachment promotes intelligence which leads to a successful learning of all abilities in life. Therefore a good parent and teacher orientation is fundamental to promote future learning.

This orientation is based on very simple concepts. Although they are simple they are not easy to be put in practice because some caregivers are not prepared for the arrival of a baby. If this mother does not have conditions to take care of the baby it is very important that another caregiver can do it in this moment because the baby cannot stay without assistance during a long period of time. Coriat and Jerusalinsky [7] affirm that the fragility of a baby does not admit delays, the consequences of this maternal separation can get worse and continue for many months becoming irreversible.

Still face experiment reflects about this matter and proves that babies become very distressed with the unresponsiveness of their mothers. Babies are very sensible to perceive their mother's behavior and emotions. This experiment shows the importance of early parental involvement and availability. The still face experiment proposed by Tronick [8] presents the infant-mother relationship. The mother is asked to interact with the baby normally and after some minutes stop this interaction remaining with her face paralyzed and unresponsive. This attitude causes a negative reaction on the baby who seems to struggle to recuperate the attention and the social interaction with his mother. It is quick and clear to watch the stress and the sadness building up on the baby who is deprived of social interaction.

Experiments indicate modifications on the neuroendocrinous and behavioral systems of these babies who have suffered deprivation or stress during the beginning of their development. Neuroscience indicates that early experiences influence on the growth of the brain and its functions. Experiments of positive affection related to moments of pleasure and security are the main cause of the increase of synaptic communication.

Several studies prove that babies of depressed mothers show a poor interaction with strangers and have more expressions of sadness and anger. Cunha [9] points out that there is an important sensibility of the hypothalmic-pituitaryadrenal gland of babies who pass through stressful situations in their childhood. There is an increase on the level of basal salivary cortisol of the babies of depressed mothers which cause decrease on the synaptic density and on the serotonine. Motta [10] adds that the heart frequency of babies of depressed mothers is considered higher.

Jones [11] affirms that these babies present in their EEG exam more activation of the right frontal region than of the left. Field [12] and Jones [11] consider that the activation of the right frontal region is associated with emotions which reflect affected deprivation. Depressed mothers need family, therapeutic and social support so that they can perform their essential maternity which is fundamental to promote the pattern of neurological, neuroendocrinous and psychological development to their babies.

Leal [13] points out to the existance of an innate impulse which looks for the reaction on the other person. The baby tries to have a relation with the other who seems to him like a legitimate and responsive person. Based on this search of responses to spontaneous iniciatives we believe that a good parent orientation prepares these parents on the promotion of a better motor, cognitive and affective development to their children.

In this moment we will propose some basic orientations to caregivers of babies:

- Pay attention to the initiatives of this baby and respond to them showing that you are present within this dynamic.

- Give holding. Hold the baby firmly and safely to pass security. Be entire and complete in the relationship

- Look the baby in the eyes when changing dippers, when breastfeeding and in all occasions when together to create visual, tactile and auditory contact.

- Emphasize the emotions that appear. Let the emotions emerge and nominate them.

- Be entire and complete in the relation.

- Touch your baby and nominate where you are touching and the tender feelings that emerge.

- Talk to your baby. Establish a relation with him.

- When the baby does a gesture, do the same gesture back to show that you are with him, following him.

- When the baby emits a sound, baby talk back to the baby, communicate in a sensible way with your baby.

- It is important that your baby notices the attention given to him.

- Time with quality promotes brain development and builds up the personality of the baby.

- The nervous maturity occurs by means of social interaction.

These orientations are used to compose a flyer which will be distributed in a city close to São Paulo to pregnant 
parents. The orientations will serve as a guide to promote a better and healthier psychological development to the baby, as well as a psychomotor development which is fundamental for the learning of school abilities.

Leal [13] emphasizes that the communication that occurs back and forth is observed in the early years of a babies' life. She considers it is the root of the motor, affective and cognitive development. Within this communication a relation of two or more people is present which builds up the subjectivity of the human being.

Vygotsky [2] affirms that such instruments, actions and social relations are presented to the child, in first hand, in an interpsychological and social level and, only afterwards, it will occur in an intrapsychological, internal and subjective level through the process of internalization.

\section{ORIENTATIONS TO TEACHERS}

The school serves as a mediator of knowledge and education. Well prepared teachers will work in zone of proximal development to complement and promote the development of children.

Vygotsky [2] explains the zone of the proximal development as the opportunity of positioning beside the child helping and permitting him to reach the next development. In this way the mediator helps in the development and growth which promotes the passage from a level of potential development to real development, when the child is already able to do the activity himself.

Strategies will be pointed out to facilitate and stimulate the teacher for a better development of the superior mental functions of their students. It is important to emphasize that significant relation and interpersonal contact promote development:

- Consider that each individual person has different characteristics of personality.

- Teach each student individually because they are different people therefore unique and particular.

- Respect the initiatives of the students and try to respond to all of these initiatives.

- Look the students in the eyes and be sensible to their needs.

- Work in a go-and-come-back rhythm. Initiative response.

- Propose a team work where two students work together, people working together exchange informations, practice their relations and all the implications that come with this.

Well orientated teachers should use strategies to work and promote the development of the three functional units of Luria [14]:

First Unit: localized on the brain stem responsible for the activation of the brain and for the vigil state.
- Several psychomotor exercises should be done to activate the brain and also for attention. Exercises as: "Simon says touch your nose... Simon says touch your elbow... Simon says put your hands up... put your hands down" - in this exercise the child should do what Simon says and the child should not do what Simon did not say. The child has to be activated and attentive to do this exercise correctly.

- Another movement exercise to activate the child is "head, shoulder, knees and toes, knees and toes..." Then take away the words and just do the movements. To be able to do this exercise shows how awake and alert is the child

- Memory exercises like: "John went to the fair and bought an orange... John went to the fair and bought an orange and an apple"... and so on also stimulates the brain stem activating the child.

- These exercises prepare the students for the curricular activities activating their brain and promoting a good field of attention.

Second Unit: this functional unit is responsible for the reception, processing and storage of informations.

- It is importante to use tactile (parietal lobe), visual (occipital lobe) and auditory material (temporal lobe) to stimulate all of the senses of the children.

- Repete all the informations given in class to incentivate the students to participate. The teacher should do a "to do list" of the day and as he gives classes fill in the list with informations so that the students will have all the important infomations of that day in a systematized and organized way in their notebooks for posterior study.

- It is important for the children to have various stimulus: psychomotor, visual, tactile and auditory. All of them together will help on the codification and storage of the informations in the memory.

Third Unit: This functional unit of the Functional System of Luria [14] is responsible for the organization, planning, anticipation of the action, problem solving, correction of errors and postponement of impulses.

- Use games and activities to stimulate the thought and the planning from a psychomotor point of view and also to improve cognitive aspects. Some advised games which work the executive functions are: chess, mastermind, sudoku, card game of letters, etc.

- Body movements are also important for control, orientation and for interhemispherical interactions. These exercises can be done at school or with private professionals as speech therapists, neuropsychologists, psychologists, private teachers, etc. 
Luria [14] affirms that the brain works as in a concert, all of the three units work together forming the Functional System. One unit helps the other in an interdependent way.

\section{CONCLUSION}

We believe that the most important is not WHAT TO DO but HOW TO DO. Therefore parents and teachers should establish a good relation with their children and students, considering them as unique individuals providing development to occur. Parents and teachers with a good orientation and compromised with the well being of the child are able to promote cognitive development to these children. A team work among school and family is fundamental.

Parents and teachers serve as mediators of the world to their child. In this way they are both responsible for presenting the world and all concerned within it to this child. This responsibility involves the way the child will internalize the world because his subjectivity will be built within the relations he has and his experiences in life.

Bock [1] affirms that man transforms and is transformed in a constant process. Therefore relationships involve exchange, in both ways, one constitutes the other, transforms the other, in a process which focuses the best adaptation to reality.

We believe that orientation is a very important tool when we think about preparing a person to generate and promote a good and significant relation with the child. We recognize that: attention, tenderness and love are the principal tools among a relation between caregiver and a baby as well as between teacher and students providing a better development of the superior mental functions of the child.

\section{CONFLICT OF INTEREST}

The authors confirm that this article content has no conflicts of interest.

\section{ACKNOWLEDGEMENTS}

\author{
Declared none.
}

\section{REFERENCES}

[1] Bock AMB, Gonçalves MGM, Furtado O. Psicologia SócioHistórica (uma perspectiva crítica em psicologia). São Paulo: Cortez Editora 2002.

[2] Vygotsky LS. A Formação Social da Mente. São Paulo: Martins Fontes 1994

[3] Amiralian MLTM. Deficiências: Um Novo Olhar. Contribuições a partir da Psicanálise Winnicottiana. Estilos da Clínica, 2003; (VIII)15: 94-111.

[4] González Rey F. Personalidad y desarrollo. Havana: Pueblo y Educación 1995

[5] Aguiar WMJ. Consciência e atividade: Categorias fundamentais da Psicologia Sócio-Histórica. In: Bock AMB, Gonçalves MGM, Furtado O Eds. Psicologia Sócio-Histórica (uma perspectiva crítica em psicologia). São Paulo: Cortez 2002; pp. 95-110.

[6] Vygotsky LS. Obras Escogidas. España: Visor, 1995.

[7] Coriat LF, Jerusalinsky AN. Definição de Estimulação Precoce. Escritos da Criança, no. 1, Porto Alegre, $2^{\text {nd }}$ ed. 1993; pp.72-5.

[8] Tronick EZ. Emotions and emotional communication in infants. Am Psychol 1989; 44(2): 112-9.

[9] Cunha I. A revolução dos bebês: aspectos de como as emoções esculpem o cérebro e geram comportamentos no período pré e perinatal. Psicanalítica - Revista da SPRJ. Rio de Janeiro 2001; II(1): 102-28.

[10] Motta MG, Brunstein C, Luz C, Perrone S, Lucion AB, Manffro GG. Alterações no eixo do estresse em bebês de mães deprimidas. Achados preliminares. Poster apresentado na IX Jornada Gaúcha de Psiquiatria da Região Sul, IV Jornada Gaúcha em julho de 2002.

[11] Jones NA, Field T, Davalos M. Right frontal EEG asymmetry and lack of empaty in preschool children of depressed mothers. Child Psychiat Hum Develop 2000; 189: 205-30.

[12] Field T, Pickens J, Fox N. Vagal tone in infants of depressed mothers. Develop Psychobiol 1995; 227: 231-7.

[13] Leal MRM. Comunicação Primária e Intercâmbio Mutuamente Contingente. São Paulo: Terceira Margem 2003.

[14] Luria AR. Fundamentos de Neuropsicologia. São Paulo: E.P.U. 1981.

$\begin{array}{lll}\text { Received: November 02, } 2014 & \text { Revised: December 29, } 2014 & \text { Accepted: January 28, 2015 }\end{array}$

(c) Carla Anauate; Licensee Bentham Open.

This is an open access article licensed under the terms of the Creative Commons Attribution Non-Commercial License (http://creativecommons.org/licenses/bync/3.0/), which permits unrestricted, non-commercial use, distribution and reproduction in any medium, provided the work is properly cited. 